108 Наукові записки ХНПУ ім. Г.С. Сковороди. Літературознавство, 2019, вип. 4(94)

УДК 821.161.2.09“1920/1930”

Л.М. Кулакевич

\title{
ІРОНІЧНИЙ МОДУС ШПИГУНСЬКОЇ ПОВІСТІ Ю. СМОЛИЧА «ПІвТОРИ людИнИ»
}

Художній здобуток українського письменника Юрія Смолича ще не став об'єктом системного наукового дослідження. Наявні хіба що нариси життя і творчості письменника, написані 3. Голубєвою, Є. Старинкевичем, С. Шаховським, нечисленні студії його творчості Ю. Артюшенка, О. Міськова, А. Носко, В. Олефір, В. Піскунова, Л. Танюка, В. Чапленка. Демонстративна байдужість українських радянських науковців до творів Ю. Смолича, відверте ігнорування його здобутків сучасними українськими літературознавцями, на нашу думку, є «покаранням» письменника за таємну співпрацю 3 органами НКВД / КГБ. Як іронічно зауважив М. Васьків, попри те, що в радянські часи кожен поважний літературознавець вважав своїм обов’язком послатися на «Фальшиву Мельпомену», не читаючи роман, твори письменника залишалися поза літературним процесом, для них навіть, не знайшлося місця в «Історії української літератури XX століття»: «Загалом із доброго десятка довоєнних романів Ю. Смолича у післявоєнний період перевидавалися тільки "Прекрасні катастрофи” і “Театр невідомого актора". Решта ж його романів 20-30-х, надзвичайно цікавих своїм пошуковим характером, експериментаторством (чого варті лише назви творів іїх підзаголовки: “Останній Ейджевуд”, “Півтори людини”, “По той бік серця: Неймовірні, і дедалі-неймовірніші, пригоди парубка з променистими очима та його побратима з великим заростом на лобі. Роман-хроніка 3 життя одного мого знайомого”, “Сорок вісім годин: книга про те, що було, що мало бути, що могло бути і чого не було” та ін. ) для сучасного читача невідомі» [1, с. 7]. Актуальність вивчення творчого здобутку письменника зумовлена тим, що саме Ю. Смолич вважається зачинателем шпіонської прози, а також української наукової фантастики, хоча В. Смирнів відмовляє письменнику в (C) Л.М. Кулакевич, 2019

http://dx.doi.org/10.34142/2312-1076.2019.4.94.08 
цьому, звинувачуючи його в заангажованості: «Будучи письменником iз досить обмеженою уявою, Ю. Смолич присвятив себе не просуванню нових наукових або технічних ідей, а пропаганді радянських ідеологічних приписів» [4, с. 67]. Ми переконані, що для повної картини літературного процесу в Україні в 20-30 pp. ХХ ст. вивчення творчого здобутку цього культурного діяча $є$ необхідною.

Шпигунська проза була відносно новим жанром в українській літературі 20-30 pp. ХX ст. Традиційно твори про шпигунів розглядаються як різновид детективної літератури, а в ширшому значенні - масової літератури. Та якщо в основі детективу лежить злочин (убивство, пограбування, шахрайство), то основою шпигунської прози $є$ оповідь про політичну, розвідувальну чи диверсійну діяльність шпигунів, які для потреб Вітчизни збирають інформацію в тилу ворога чи просто за гроші передають важливу інформацію ворогам на шкоду власній державі. Власне шпигунський жанр представлений в українській літературі 20-30 pp. ХХ ст. повістями Ю. Смолича «Півтори людини» (1927), О. Досвітнього «Нас було троє» (1928). Якщо останній твір, на нашу думку, є найбільш репрезентативним у жанрі шпигунського наративу, то повість Ю. Смолича - у жанрі іронічного шпигунського наративу.

Відповідно до жанрового канону шпигунського роману героєм повісті Ю. Смолича «Півтори людини» $\epsilon$ пересічна людина, звичайний інженер-початківець Смик, який приїздить до Кічкаса (передмістя Запоріжжя) на будову Дніпрельстану. У героя відсутній внутрішній конфлікт, немає й проблеми, що ускладнювала б йому життя, до дій його спонукають лише зовнішні обставини: Смик зазнає нападу від невідомої людини. Читач так і не дізнається, хто і за що вдарив інженера-початківця, адже чекісти, безапеляційно відкидаючи звичайне розбишацтво, вбачають у діях невідомого контрреволюційний слід, не маючи жодних доказів. Наївний інженер береться встановити особу нападника.

Вже $з$ перших рядків оповіді, в яких через деталі свого руху потяг, що везе Смика, викликає асоціації з грайливим цуциком («то біг підтюпцем, наввипередки з курявою», «то притамовував швидкість і 
злазив на горбок ходою», то «плентався понуро» [5, с. 201]), відчувається іронічне ставлення до інженера. Н. Городнюк, аналізуючи семантику машин, зокрема поїзда i залізниці в модерністських романах першої половини XX ст., підкреслює, що художня інтерпретація машини та потрактування техніки загалом $\epsilon$ виразним ідейно-естетичним й ідеологічним маркером літератури 20-30-хрр. ХХ ст. При цьому дослідниця запевняє, що «саме образ машини постає своєрідним лакмусовим папірцем стилю, демонструючи його концептне поле, головні світоглядні орієнтації, ідеї та емоції, визначаючи тематику та проблематику його текстів» [2, с. 473]. Спираючись на цю тезу, з упевненістю можемо стверджувати, що «грайливий поїзд» уречевлює емоційну недозрілість, життєву інфантильність головного героя, що засвідчено й особливостями його рефлексій, зіставними 3 рухом потяга: «Думалося про різне і ні про віщо. Думки зринали й зникали за рухом поїзда: то бігцем з горбочка, то в млявій інертності й без пуття» [5, с. 202]. Пересічність умовиводів актанта виявляється в епізоді, коли Смик, сидячи у вагоні в кашкеті інженера, дивується, що випадковий сусід називає його інженером. Високий пафос постійних рефлексій героя щодо краси будівництва нівелюється іронічними зауваженнями щодо стану навколишнього світу: «Все це принишкло у своїй дурній непорушності й чекало на свою загибель від руки цієї мізерної точки, що неввічливо, пузом, розляглася на грудях старезного степу» [5, с. 219].

За шпигунським каноном головний актант повинен бути уважним до деталей, вміти думати аналітично, однак герой Ю. Смолича позбавлений усіх цих рис, йому властива гіпертрофована підозрілість, він повільно сприймає інформацію, мало коли робить правильні висновки, емоції, які той переживає під час пошуку злочинця, не властиві ловцям шпигунів («зовсім здурів у вирі незрозумілих, чудних подій» [5, с. 264], «трохи не заплакав» [5, с. 266] тощо). Здавалося б, що людина, яка здобула технічну освіту, повинна бути емоційно врівноваженою, керуватися здоровим глуздом, бути практичною, без сантиментів ставитися до життя (бо таким постають 
Рудольф Штор («Сонячна машина» В. Винниченка), Гарі Руперт («Пригоди Мак-Лейстона, Гаррі Руперта та інших» М. Йогансена), Володимир («Останній Ейджевуд» Ю. Смолича) Артем Гайдученко («Чорний ангел» О. Слісаренка), Михайло Різдвянський («За силу сонця» М. Чайковського), однак герой повісті «Півтори людини» не відповідає таким характеристикам. Можна говорити про «перевернутість» штампів шпигунського наративу в тексті Ю. Смолича, адже у статусі компаньйона простацького Смика опиняється агент ДПУ, наділений рисами супермена - ставний, доглянутий Анатоль Чепурний, який видає себе за журналістафрилансера («Я ніде ніколи не працюю за постійного співробітника. Не можу знести, щоб керували моїми думками, примушували робити те, а не те. 3 власної ініціативи я засилаю матеріали до різних журналів» [5, с. 221]. Є деталі, які видають у випадковому супутнику Смика сищика і відсилають до конандойлівського Шерлока Холмса: Чепурний «курив люльку» й уважно, не поспішаючи, оглядав місцевість [5, с. 204].

Сюжет полювання на шпигунів ускладнено додатковими лініями, a ïx перетинання породжує комізм ситуацій, у які потрапляє головний герой. Так, у «Розділі третьому, який свідчить про те, що ніхто не гарантований, що йому нишком не розвалять голову цеглиною» [5, с. 223] Смик несподівано стає жертвою нічного нападу, справжні мотиви якого так і за лишаться нерозкритими. Іронія із штампів такого серйозного літературного жанру як шпигунський роман, виявляється в і залученні до повісті дискурсу любовного роману: у творі діє красуня, на яку претендують старий Глущак, хвацький Чепурний і простодушний Смик: «Була то молода жінка видатної вроди. В іiї розпанаханому, очевидячки, хатньому туалеті виглядала вона й зовсім красунею. Якась наче хижа краса була в овалі іiі обличчя, у високому чолі, що загострювалося тонким правильним носом, у її темних очах, у шапці густого чорного волосся» [5, с. 207]. Відповідно до канону шпигунського наративу згодом виявляється, що Гелена є спільницею і коханкою контрреволюціонера. Ім'я героїні відсилає до грецького міфу про боротьбу чоловіків за Єлену 
Троянську. Як і міфологічна молода жінка, Геля гине від руки своєї служниці Килини, яка, по суті вбиває свою господиню, заздрячи останній за надмірну увагу чоловіків. Трагічність сцени нівелюється натуралістичними деталями посмертної долі тіла красуні, що роблять іï карикатурною («нежива Геля розкинула руки й ноги» [5, с. 264], вона «задубіла горілиць» [5, с. 265]; «При згадці про Гелю огида перебігла Смиковим тілом. Він уявив собі мертвяка, розпростертого на долівці», герой не наважується повернутися додому, бо там «<...> гнив смердючий труп тієї, яку він трохи не покохав, яку кликав собі у спільники...» [5, с. 267]). Згідно 3 літературними штампами, герой любовного роману повинен ще довго страждати, дізнавшись про злочинність коханої жінки, любити іiї навіть після спроб вбити його, та, як бачимо, у повісті Ю. Смолича почуття романтично закоханого Смика миттєво випаровуються в момент загибелі Гелі.

Моделюючи образи шпигунів, письменник іронізує зі стереотипів масової свідомості, згідно з якими вороги обов'язково мають куркульське чи дворянське коріння $€$ підступними й аморальними, у зв'язку з чим у повісті розгортається мотив інцесту. Гелена і Глущак поводяться нелогічно (видають себе за дочку й батька, при цьому вдаються до любощів на природі, де їх можуть заскочити в будь-яку мить; полюють на вулиці за планом, який можна спокійненько скопіювати в себе вдома, адже Смик поселяється в їхньому будинку тощо) відверто абсурдною $є$ й сама мета злочинців - вкрасти план ще не побудованого Дніпрельстану. Відповідно до літературного штампу вловлений шпигун повинен розкрити всі карти своєї діяльності (що шукав, кому і з якою метою передавав інформацію), однак у повісті Ю. Смолича використано мінус-прийом: Геля i Глущак гинуть, так і не розказавши, кому мали б вручити план і чи збиралися взагалі його красти.

Маємо всі підстави вважати повість Ю. Смолича «Півтори людини» пародією на шпигунський роман. Ураховуючи те, що сама повість $€$ по суті першим репрезентантом жанру шпіонського роману в українській літературі, слід говорити про пародіювання саме 
зарубіжних творів. Послуговуючись термінами сучасного літературознавства, повість можна було б точніше означити як іронічний шпигунський детектив. Пародійність виявляється не тільки в нанизувані безглуздих ситуацій, але й у порушенні єдності теми і стилю оповіді. Про надважливі для держави речі - загрозу знищення стратегічних об'єктів народного господарства оповідається низьким стилем, що оприявнюється вже на рівні назви твору. В. Марко, розкриваючи сутність, принципи, цілі та загальні прийоми аналізу твору, як феномену літератури в іiі жанровостильовому розмаїтті, зазначив: «Від назви до останнього речення все в творі змістово навантажене» [3, с. 137]. Винесений у назву розмовно-жартівливий фразеологізм «півтори людини» означає «майже нікого не було». У контексті змісту повісті це можна декодувати як абсурдність титанічних зусиль Смика, Чепурного i Мадюді, спрямованих на знищення ворога, адже загроза з боку Глущака та його чарівної коханки існувала хіба що в уяві ловців контрреволюціонерів. До такого висновку підштовхують й розмовнопросторічні елементи в заголовку «Розділ четвертий, що в ньому старий чекіст Мадюдя муляє собі мозок і (хоч йому роди) дошукується контрреволюції» [5, с. 233]. Вказівка на роботу мислення чекіста «муляє собі мозок» - оприявнює надуманість його розуміння ситуації, а вислів «хоч йому роди» вказує на бажання знайти шпигунський слід навіть там, де його апріорі бути не може. Фабульні заголовки до розділів повісті є ключовим інструментом іронії, адже, задаючи сюжетну перспективу, вони дисонують 3 описуваними в них подіями, увиразнюючи карикатурність останніх. Так, у «Розділі другому, що в ньому Смик, лежачи долічерева, індустріалізує дикунську країну, а втомившись, нюхає квіти» [5, с. 211] зад Смика стає достойним об'єктом для фотосесії Чепурного. А в «Розділі сьомому, про сім непорозумінь і одну смерть, Що ж до старого пана Глущака, то його не задовольняє амплуа настінного портрета» смерть Гелі стається на фоні комічної ситуації ховання Глущака за портретом українського гетьмана: «Перший опам'ятався придуркуватий пан. Він жалібно заскиглив, переляканий, зашамотався по хаті, кривлячись 
й шкірячись із піною на вустах. Потім кішкою плигнув на стілець i заховався за портрет одного з настінних гетьманів. Тонкий папір не витримав, тріснув уздовж, і перелякана ідіотові пика висунулася 3 рами, заступивши місце гетьмана. Хоч і як був схвильований Чепурний під люфою Смикового револьвера, проте видовище було таке сміховинне, що не витримав він і всміхнувся» [5, с. 263]. Іронія у повісті «Півтори людини» досягається і через постійне використання розмовно-просторічної зниженої лексики для означення дій і станів «мисливців за шпіоном».

Твір Ю. Смолича сприймаємо як пародію не тільки на шпигунський наратив, але й шпигуноманію, що на початку XX ст. охопила мало не увесь світ і радянське суспільство зокрема. Під впливом стратегії контррозвідки, яка через засоби масової інформації навіювала населенню думку про невпинну діяльність ворожих робітничоселянській владі класових елементів, гіперболізувала їхню небезпеку для Радянського Союзу, до полювання на шпигунів долучилися пересічні громадяни, «узріваючи» контрреволюційну діяльність у діях «незручних» сусідів по комунальній квартирі чи колег по роботі.

Отже, у повісті Ю. Смолича пародіюються не тільки літературні канони, але й атмосфера 20-30 років ХХ ст., коли обивателі вишукували між собою агентів зарубіжних спецслужб, ворожих владі. Кліше шпигунського роману максимально оголене (центральний персонаж випадково опиняється у вирі загадкових подій, стає жертвою таємничого нападу і розпочинає власне слідство, у результаті чого буде викрито двох контрреволюціонерів), іронія досягається використанням зниженої лексики, уведенням деталей і ситуацій, що не відповідають традиційним шаблонам шпигунського жанру.

\section{Література}

1. Васьків М.С. Український роман 1920-х - початку 1930-х років: генерика й архітектоніка. Кам'янець-Подільський: Буйницький О.А., 2007. 208 c.

2. Городнюк H.A. Res incognita: семіотика речі у східнослов'янському модерністському романі першої половини $\mathrm{XX}$ століття. Дніпро: Свідлер А.Л., 2017. 560 с. 
3. Марко В.П. Аналіз художнього твору. Київ: Академвидав, 2013.280 с.

4. Смирнів В. Українська фантастика. Харків: Мачулін, 2019. 436 с.

5. Смолич Ю. Півтори людини. Постріл на сходах. Детектив 20-х років. Київ: Темпора, 2017. С. 201-274.

\section{References}

1. Vaskiv M.S. Ukrainskyiroman 1920-kh - pochatku 1930-kh rokiv: generyka y arkhitektonika. [Ukrainian novel of the 1920s - early 1930s: Generics and architectonics]. Kamianets-Podilskyi: Buinytskyi O. A., 2007. 208 p.

2. Horodniuk N.A. Resincognita: semiotykarechi u skhidnoslovianskomu modernistskomu romani pershoi polovyny XX st. [Res incognita: the semiotics of things in the East Slavic modernist novel of the first half of the XX century]. Dnipro: Svidler A. L., 2017. 560 p.

3. Marko V.P. Analiz khudo zhnoho tvoru. [Analysis of a literary work]. Kyiv: Akademvydav, 2013. 280 p.

4. Smyrniv W. Ukrainian Science Fiction [Historical and Thematic Perspectives]. Kharkiv: Machulin, 2019. 436 p.

5. Smolych Y. Pivtory liudyny. Postril na skhodakh. Detektyv 20-kh rokiv. [One and a Half People. Gunshot on the stairs. Detective of 20s]. Kyiv: Tempora, 2017. P. 201-274.

\section{Анотація \\ Л.М. Кулакевич. Іронічний модус шпигунської повісті Ю. Смолича «Півтори людини»}

Метою статті є визначення жанрово-стильових особливостей повісті як репрезентанта іронічної шпигунської прози. Виявлено, що кліше шпигунського роману максимально оголене (центральний персонаж випадково опиняється у вирі загадкових подій, стає жертвою таємничого нападу і розпочинає власне слідство, у результаті чого буде викрито двох контрреволюціонерів). Встановлено, що відповідно до жанрового канону шпигунського роману героєм твору є пересічна людина, звичайний інженерпочатківець Смик. За шпигунським каноном головний актант повинен бути уважним до деталей, вміти думати аналітично, однак герой Ю. Смолича позбавлений усіх цих рис, йому властива гіпертрофована підозрілість, він повільно засвоює інформацію, мало коли робить правильні висновки, емоції, які той переживає під час пошуку злочинця, не властиві ловцям шпигунів. Звертаємо увагу на «перевернутість» штампів шпигунського 
наративу в тексті Ю. Смолича, адже у статусі компаньйона простацького Смика опиняється агент ДПУ, наділений рисами супермена. В образі останнього підкреслено деталі, які відсилають чекіста до конандойлівського Шерлока Холмса. Сюжет полювання на шпигунів ускладнено додатковими лініями, їх перетинання породжує комізм ситуацій, у які потрапляє головний герой. Моделюючи образи шпигунів, письменник іронізує зі стереотипів масової свідомості, згідно з якими вороги обов'язково мають куркульське чи дворянське коріння є підступними й аморальними, у зв'язку з чим у повісті розгортається мотив інцесту. Відповідно до літературного штампу шпигун повинен розкрити всі карти своєї діяльності, однак у повісті Ю. Смолича використано мінус-прийом: контрреволюціонери гинуть, так і не розказавши, кому мали б вручити план і чи збиралися взагалі його красти. Акцентовано, що повість Ю. Смолича є пародією на шпигунський роман. Послуговуючись термінами сучасного літературознавства, повість можна було б точніше означити як іронічний шпигунський детектив. Пародійність виявляється не тільки в нанизувані безглуздих ситуацій, але й у порушенні єдності теми і стилю оповіді. У повісті пародіюються не тільки літературні канони, але й атмосфера 20-30 років XX ст.. Іронія досягається використанням зниженої лексики, уведенням деталей і ситуацій, що не відповідають традиційним шаблонам шпигунського наративу.

Ключові слова: авантюрно-пригодницька проза, шпигунський жанр, канон шпигунського роману, образ шпигуна, засоби іронії.

\section{Аннотация \\ Л.Н. Кулакевич. Иронический модус шпионской повести Ю. Смолича «Полтора человека»}

Целью статьи является определение жанрово-стилевых особенностей повести как репрезентанта иронической шпионской прозы. Выявлено, что клише шпионского романа максимально обнаженное (центральный персонаж случайно оказывается в водовороте таинственных событий, становится жертвой таинственного нападения и начинает собственное расследование, в результате чего будут разоблачены два контрреволюционера). Установлено, что в соответствии с жанровым каноном шпионского романа, героем произведения является обычный человек, молодой инженер Смык. По шпионским канонам главный актант должен быть внимательным к деталям, уметь думать аналитически, однако герой Ю. Смолича лишен всех этих черт, ему свойственна 
гипертрофированная подозрительность, он медленно усваивает информацию, редко делает правильные выводы, состояния и эмоции, которые он переживает во время поиска преступника, совсем не подходят охотникам на шпионов. Обращаем внимание на «перевернутость» штампов шпионского нарратива в тексте Ю. Смолича, ведь в статусе компаньона простецкого Смыка оказывается агент ГПУ, наделенный чертами супермена. В образе последнего подчеркнуты детали, которые отсылают чекиста к конандойловскому Шерлоку Холмсу. Сюжет охоты на шпионов усложнен дополнительными линиями, их пересечения порождают комизм ситуаций, в которые попадает главный герой. Моделируя образы шпионов, писатель иронизирует над стереотипами массового сознания, согласно которым враги обязательно имеют кулацкие или дворянские корни, они коварные и аморальные, в связи с чем в повести разворачивается мотив инцеста. Согласно литературному штампу пойманный шпион должен раскрыть все карты своей деятельности, однако в повести Ю. Смолича использован минусприем: контрреволюционеры погибают, так и не рассказав, кому должны вручить план и собирались ли вообще его похищать. Акцентировано, что повесть Ю. Смолича является пародией на шпионский роман. Пользуясь терминами современного литературоведения, повесть можно было бы точнее обозначить как иронический шпионский детектив. Пародийность проявляется не только в нанизывании нелепых ситуаций, но и в нарушении единства темы и стиля повествования. В повести пародируются не только литературные каноны, но современная писателю действительность. Ирония достигается использованием сниженной лексики, введением деталей и ситуаций, которые не отвечают традиционным шаблонам шпионского нарратива.

Ключевые слова: авантюрно-приключенческая проза, шпионский жанр, канон шпионского романа, образ шпиона, средства иронии.

\section{Summary}

\section{L.M. Kulakevych. The ironic modus of spy novella by Y. Smolych «Pivtory liudyny» («One and a Half Man»)}

The purpose of the article is to identify the peculiarities of genre and style of the novella as a representative of the ironic spy prose. It is revealed that the cliché of the spy novel is highly obvious (the main character accidentally falls into the stream of mysterious events, becomes a victim to a mysterious attack and starts his own investigation, which later exposes two counter-revolutionaries). It is established that according to the genre canon of the spy novel the main character 
is the ordinary person, the junior engineer Smyk. According to the spy canon, the main actant must be attentive to the details, be able to think analytically, however, the character of Y. Smolych is deprived of all these features: he is over suspicious, he digests information slowly, almost never makes the right conclusions, the emotional and behavioral patterns when he is searching for criminals do not fit those of true spy hunters. We point out the «inverted» cliché of the spy narrative in the text of Y. Smolych because the companion of such an ordinary person as Smyck is a handsome superman-like DPU agent Anatol Chepurnyi. Quite noticeable details of his image refer to Conan Doyle's Sherlock Holmes. Additional lines complicate the plot and the main character falls intocomic situations generated by their intersection. While modeling the images of spies, the writer mocks the stereotypes of the mass consciousness of the time, according to which the enemies must have a kulak or noble roots, they are insidious and immoral, and for this reason, the motive of incest unfolds in the novella. According to the literary cliché, the captured spy must disclose all the cards up his sleeve; however, Y. Smolych used a negative device: Helia and Hlushchak got killed never telling whom they were supposed to hand the blueprints or whether they were going to snatch them at all. It is essential that we regard Y. Smolych's novella as spy novel parody. Using the terms of modern literary criticism, it is more accurate to consider it as an ironic spy detective. Parody manifests itself not only in a string of meaningless situations, but also in violation of the unity of the theme and style of narrative. Not only literary canons are parodied in Y. Smolych's novella, but the reality as well. Irony is achieved through the use of low lexis, introduction of the details and situations that do not fit in the traditional spy narrative patterns.

Keywords: adventure prose, espionage genre, spy novel canon, image of spy, irony literary devices.

\section{Інформація про автора}

Кулакевич Людмила Миколаӥвна - кандидат філологічних наук, доцент кафедри українознавства ДВНЗ „Український державний хімікотехнологічний університет”; м. Дніпро, просп. Гагаріна, 8,Україна; e-mail: leda4a@gmail.com; https://orcid.org/0000-0002-2405-8894. 